\title{
Applying Artificial Neural Networks In Construction
}

\author{
Anna Doroshenko ${ }^{1, *}$ \\ ${ }^{1}$ Moscow state university of civil engineering, 129337 Moscow Yaroslavskoe sh. 26
}

\begin{abstract}
Currently, artificial neural networks (ANN) are used to solve the following complex problems: pattern recognition, speech recognition, complex forecasts and others. The main applications of ANN are decision making, pattern recognition, optimization, forecasting, data analysis. This paper presents an overview of applications of ANN in construction industry, including energy efficiency and energy consumption, structural analysis, construction materials, smart city and BIM technologies, structural design and optimization, application forecasting, construction engineering and soil mechanics.
\end{abstract}

\section{Introduction}

The construction industry has a lot of separate automated solutions from the design process to logistics and planning, but often these information systems are incompatible with each other, which is a limitation for creating effective machine learning and artificial intelligence systems. And that is why the digital transformation of processes in construction is expressed rather weakly in comparison with other industries. The potential of solutions based on artificial intelligence can be realized only through the integration of all sources of heterogeneous data [1].

The concept of neural network appeared in the fifties of the twentieth century.

In 1943, Warren McCulloch and Walter Pitts published an article [2] which first described a mathematical model of a neural network.

In 1949, neuropsychologist Donald Hebb published the book [3] in which the first working learning algorithm for artificial neural networks was proposed.

In 1962 Frank Rosenblatt, based on his lectures, published the book [4], in which an attempt is made to give a rigorous mathematical theory of construction to the functioning of artificial "nerve networks" ("neurodynamic") and provides extensive material on already conducted and planned experiments with "perceiving" and "cognitive" systems, united under the general name "perceptron".

However, in 1969, a former fellow student of Rosenblatt Marvin Minsky and Seymour Papert published the book [5], in which they presented rigorous mathematical proof that the perceptron is not capable of learning in most interesting cases. As a result of the adoption of ideas and conclusions of the book by $\mathrm{M}$. Minsky and S. Papert, work on neural networks was curtailed in many scientific centers and funding was substantially cut.

In 1974, Paul Verbos developed a back-propagation error algorithm, which is still used today for training artificial neural networks. Since 1985, John Hopfield has been offering the world his vision of the design and operation of a neural network that is capable of solving certain types of problems. It is the work of John Hopfield that once again fuels the serious interest of the world community in artificial neural networks. In the 90s of the last century, the algorithm for the back propagation of errors was significantly developed, due to which Minsky's former criticism regarding network inoperability was finally refuted. Today, ANN is the main subsection of machine learning.

\section{Artificial neural networks}

Artificial neural network (ANN) - a mathematical model, as well as its software or hardware implementation, built on the principle of organization and functioning of biological neural networks - networks of nerve cells of a living organism.

Currently, neural networks are used to solve the following complex problems: pattern recognition, speech recognition, complex forecasts.

The topic of the use of neural networks in various fields of human activity is extremely popular at the present time. This can easily be confirmed by the statistics of scientific publications on this topic (Fig. 1).

So, for example, in the Scopus database in 1986 there are two publications on the topic of ANN, in 2018 12,253 publications.

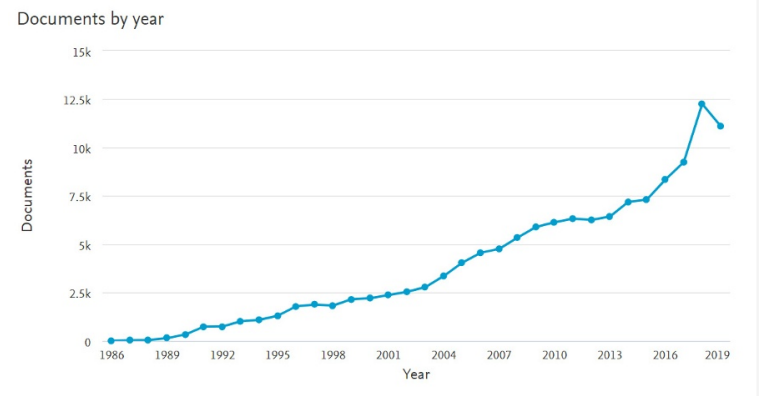

\footnotetext{
* Corresponding author: pochta.avd@gmail.com
} 
Fig. 1. The number of publications for the query "artificial neural networks" from the Scopus database (21.11.2019).

Many methods and methodologies based on the application of ANN are used in the construction industry for optimization, control, problems of identification and forecasting [1, 6-95].

\section{Applying ANN in construction}

This article provides an overview of the application of ANN in the construction industry, including energy efficiency and energy consumption, structural analysis, construction materials, smart city and BIM technologies, structural design and optimization, application forecasting, construction engineering and soil mechanics.

\subsection{Energy efficiency and energy consumption}

Neural network technologies are widely used in tasks related to energy efficiency and energy consumption in buildings [6-23]. First of all, ANN are used in the tasks of forecasting the loads on heating and cooling systems, electricity consumption and analysis of energy consumption $[6,8,11,12,14,17,18,19]$.

Neural networks are also used to study the thermal insulation properties of materials, the thermal and heat insulation property of building wall $[7,10]$.

Neural networks are used in tasks heating, ventilation and air conditioning [14, 21-23], for example for analysis and optimization of control systems of HVAC [23] and for rapidly predict non-uniform indoor pollutant concentration [21].

\subsection{Construction Materials}

The use of neural networks in building materials to predict the characteristics of building materials, for example, for studying the effect of two types of materials including micro-silica and also calcium inosilicate minerals on the compressive strength of mortars [24], for estimating the volumetric water content in different times and positions during the water imbibition inside the porous building materials [25], for predicting performance of lightweight concrete with granulated expanded glass and ash aggregate [26], for designing the composition of cement stabilized rammed earth [27], for studying on adiabatic temperature rise reflecting hydration degree of concrete [28], for predicting the compressive strength of cement-based materials exposed to sulfate attack [29], for prediction of chloride diffusion in cement mortar [30], etc. [31,32].

Neural networks are used to predict corrosion. [33,34,35].

Neural networks are also used to study the fire resistance of building materials, for example $[36,37,38,39]$.

\subsection{Safety in construction}

In addition to studying the fire resistance of building materials, neural networks are also used in other areas of construction safety, such as safety assessment of megaprojects [40], evacuation tasks [41], forecasting the safety of building structures [42], prevention various injuries at construction sites [43] and others [44].

\subsection{Soil mechanics}

ANN are widely used in the study of soil vibrations and earthquakes [45-53].

In particular, neural networks are used for predictive tunneling-induced ground movements in tunneling projects [48], for evaluating the effectiveness of mitigating ground vibration with dual or two trenches [45], for predicting the effectiveness of geofoam-filled trenches to mitigate ground vibration [47], for predicting the ground settlement along railways induced by an excavation [46], assessment of free-field vibrations due to railway traffic [51], for reliability-based cost optimization of seismically isolated structures [49] and others.

\subsection{Construction cost estimate}

One of the important aspects of construction is prediction of the behavior of the investment project model in construction at each stage of the life cycle. Neural networks have found application in the tasks of performance prediction of construction projects at different stages of projects and cost estimation in construction, predicting the quantity of materials for constructions and production rate [54-63].

\subsection{Smart city}

In smart house systems, neural networks are used for security systems, equipment control systems (heating, water supply, ventilation, light), reminder systems, monitoring and evaluation systems for objects, identification systems, etc. [64-70].

Neural networks are also used as part of urban planning and for the analysis of aerial photographs in the interests of urban economy and construction [71-72], in waste management systems [73-74].

\subsection{BIM}

The creation of information models spans all the time from the ideological concept of the project to the completion of operation and demolition of the building. Neural networks are also used in tasks related to BIM, such as creating model for spatial planning of site and building [75], multiLOD modeling approach for the early phases of building design [76], macro BIM cost analyzes [77], researching on individual thermal comfort [78] and others.

\subsection{Structural analysis}

Quite widespread neural networks are found in tasks of Structural analysis, such as: assessment of concrete strength and performance of concrete structures [79-83], 
reinforced concrete structures [84], assessment of damage states of steel structures [85], assessment of various loads [86-88], etc.

In addition to the above areas, neural networks are also used in problems of hydraulics, robotics, construction machines, in the problems of detecting various defects (for example, cracks), etc. [89-95]

\section{Conclusions}

All the tasks that neural networks can solve are somehow related to learning. Among the main applications of neural networks are decision making, pattern recognition, optimization, forecasting, data analysis.

In many areas of construction, such tasks are present.

The classical methods of statistical forecasting, recognition, classification are competitors to neural networks. Therefore, where tasks are already being solved by these competing methods, the use of neural networks is also possible, with virtually no need to reformulate or set the task in any other way. And due to the greater flexibility of neurotechnologies, the results may turn out to be much better.

\section{Acknowledgment}

This work was financially supported by Ministry of Science and Higher Education of the Russian Federation (\#NSh-3492.2018.8).

\section{References}

1. Volkov A., MATEC Web Conf., 251, 3065 (2018)

2. McCulloch W.S., Pitts W.H., Systems Research for Behavioral Science: A Sourceb., 93 (Taylor and Francis 2017)

3. Donald H., The Organization of Behaviour (John Wiley \& Sons 1949).

4. Frank Rosenblatt F., Principles of Neurodynamics. Perceptrons and the Theory of Brain Mechanisms (Spartan Books 1962)

5. Minsky M., Papert S., Perceptrons: an introduction to computational geometry (1969)

6. Das S., Swetapadma A., Panigrahi C., J. Green Build., 14, 115 (2019)

7. Orosa J.A., Vergara D., Costa Á.M., Bouzón R., Appl. Sci., 9, 2140 (2019)

8. Pezeshki Z., Mazinani S.M., Artif Intell Rev, 52, 495 (2019)

9. Beheshti S., Sahebalam A., Nidoy E., Energy Sci. Eng., 7, 338 (2019)

10. Fei X., Youfu S., Xuejun R., Cluster Comput., 22, 2255 (2019)

11. Li K., Xue W., Tan G., Denzer A.S., Build Serv Eng Res Technol (to be published 2019)

12. Song H., Qin A.K., Salim F.D., Neural Comput. Appl. (to be published 2019)
13. Lin C.-M., Lin S.-F., Liu H.-Y., Tseng K.-Y., Microsyst Technol (to be published 2019)

14. Alwisy A., Barkokebas B., Hamdan S.B., Gül M., Al-Hussein M., J. Build. Eng., 20, 387 (2018)

15. Lee J.-H., Kim Y.-S., Jo J.-H., Cho H., Cho Y.-H., Energies, 11 (2018)

16. Dong Q., Xing K., Zhang H., Sustainability, 10, 84 (2017)

17. Pino-Mejías R., Pérez-Fargallo A., Rubio-Bellido C., Pulido-Arcas J.A., Energy, 118, 24 (2017)

18. Skiba M., Mrówczyńska M., Bazan-Krzywoszańska A., Appl. Energy, 188, 356 (2017)

19. Jihad A.S., Tahiri M., Case Stud. Therm. Eng., 12, 85 (2018)

20. Kim S., Song Y., Sung Y., Seo D., Energies, 12, 433 (2019)

21. Ren C., Cao S.-J., Sustainable Cities Soc., 52, 101860 (2020)

22. Baranski M., Meyer L., Fütterer J., Müller D., Energy, 182, 840 (2019)

23. Homod R.Z., Renew. Energy, 126, 49 (2018)

24. Naderpour H., Mirrashid M., J. Build. Eng., 19, 205 (2018)

25. Nazemi E., Dinca M., Movafeghi A., Rokrok B., Choopan Dastjerdi M.H., Nucl Instrum Methods Phys Res Sect A, 940, 344 (2019)

26. Kurpinska M., Kułak L., Mater., 12, 2002 (2019)

27. Anysz H., Narloch P., Mater., 12, 1369 (2019)

28. Han Y., Fu S., Wang S., Xie Z., Adv. Mater. Sci. Eng., 2018, 1435049 (2018)

29. Chen H., Qian C., Liang C., Kang W., PLoS ONE, 13, e0191370 (2018)

30. Hoang N.-D., Chen C.-T., Liao K.-W., Meas J Int Meas Confed, 112, 141 (2017)

31. Orosa J.A., Vergara D., Costa Á.M., Bouzón R., Coatings, 9, 288 (2019)

32. Pitchaipillai N., Paramasivam S.K., Struct. Concr., (to be published 2019)

33. Shirkhani A., Davarnia D., Azar B.F., Comput. Concr., 23, 273 (2019)

34. Hoang N.-D., Tran X.-L., Nguyen H., Neural Comput. Appl. (to be published 2019)

35. Li X., Khademi F., Liu Y., Akbari M., Wang C., Bond P.L., Keller J., Jiang G., J. Environ. Manage., 234, 431 (2019)

36. Naser M.Z., Comput Mater Sci, 160, 16 (2019)

37. Naser M.Z., Constr Build Mater, 215, 192 (2019)

38. Prieler R., Mayrhofer M., Gaber C., Gerhardter H., Schluckner C., Landfahrer M., Eichhorn-Gruber M., Schwabegger G., Hochenauer C., Appl Therm Eng, 138, 217 (2018)

39. Abbas H., Al-Salloum Y.A., Elsanadedy H.M., Almusallam T.H., Fire Saf J, 106, 13 (2019)

40. Ayhan B.U., Tokdemir O.B., Saf. Sci., 118, 273 (2019)

41. Testa E., Barros R.C., Musse S.R., Visual Comput, 35, 1119 (2019)

42. Shen T., Nagai Y., Gao C., Soft Comput., (to be published 2019)

43. Jahangiri M., Solukloei H.R.J., Kamalinia M., Saf. Sci., 117, 88 (2019) 
44. Rodrigues E., Gomes Á., Gaspar A.R., Henggeler Antunes C., Renewable Sustainable Energy Rev, 94 , 959 (2018)

45. Jayawardana P., Thambiratnam D.P., Perera N., Chan T., Soil Dyn. Earthqu. Eng., 122, 107 (2019)

46. Tang Y., Xiao S., Zhan Y., Soils Found., 59, 1037 (2019)

47. Jayawardana P., Thambiratnam D.P., Perera N., Chan T., Subashi De Silva G.H.M.J., Soils Found., 59, 874 (2019)

48. Hajihassani M., Kalatehjari R., Marto A., Mohamad H., Khosrotash M., Eng Comput, (to be published 2019)

49. Moeindarbari H., Taghikhany T., J. Struct. Control Health Monit., 25, e2054 (2018)

50. Ozer U., Karadogan A., Ozyurt M.C., Sahinoglu U.K., Sertabipoglu Z., Arab. J. Geosci., 12, 60 (2019)

51. Galvín P., Mendoza D.L., Connolly D.P., Degrande G., Lombaert G., Romero A., Soil Dyn. Earthqu. Eng., 114, 598 (2018)

52. Keshav L., Srisanthi V.G., Poorna Kumar N., Disaster Adv., 11, 1 (2018)

53. Ter-Martirosyan A., Othman A., E3S Web Conf., 97, 3025 (2019)

54. Yaqubi M.K., Salhotra S., Int. J. Innov. Technol. Explor. Eng., 8, 845 (2019)

55. Hashemi S.S., Sadeghi K., Fazeli A., Zarei M., Int. J. Steel Struct., 19, 168 (2019)

56. Coloma J.F., Valverde L.R., García M., Inf. Constr., 71, e293 (2019)

57. Xiong B., Newton S., Li V., Skitmore M., Xia B., Eng. Constr. Archit. Manage., 26, 2170 (2019)

58. Rafiei M.H., Adeli H., J Constr Eng Manage, 144, 4018106 (2018)

59. Khobragade A.N., Maheswari N., Sivagami M., Int.J. Civ. Eng. Technol., 9, 1156 (2018)

60. Hassim S., Muniandy R., Alias A.H., Abdullah P., Eng. Constr. Archit. Manage., 25, 443 (2018)

61. Badawy M., Hussein A., Elseufy S.M., Alnaas K., Int. J. Constr. Manage., (to be published 2018)

62. Peško I., Mučenski V., Šešlija M., Radović N., Vujkov A., Bibić D., Krklješ M., Complexity, 2017, 2450370 (2017)

63. Fanaei S.S., Moselhi O., Alkass S.T., Can. J. Civ. Eng., 46, 609 (2019)

64. Chen S.-Y., Sens. Mater., 31, 1831 (2019)

65. Jingui Z., J. Adv. Oxid. Technol., 21, 201802010 (2018)

66. Jin W., Ullah I., Ahmad S., Kim D., Sustainability, 11, 997 (2019)

67. Ai S., Chakravorty A., Rong C., Sensors, 19, 721 (2019)

68. Reena K., Venkatesh V., Int. J. Eng. Technol., 7, 421 (2018)

69. Nicolosi G., Volpe R., Messineo A., Energies, 10, 722 (2017)

70. Lou Y., Duan L.-Y., Wang S., Chen Z., Bai Y., Chen C., Gao W., IEEE J Sel Areas Commun, 37, 1489 (2019)

71. Kim S., Kim D., Choi S., Visual Comput, (to be published 2019)
72. Popova O., Glebova J., Pustovgar A., E3S Web Conf., 33, 2032 (2018)

73. Akinade O.O., Oyedele L.O., J. Clean. Prod., 229, 863 (2019)

74. Atoyebi O.D., Awolusi T.F., Davies I.E.E., Case Stud. Constr. Mater., 9, e00185 (2018)

75. Ustinovichius L., Peckienè A., Popov V., J. Civ. Eng. Manage., 23, 173 (2017)

76. Geyer P., Singh M.M., Singaravel S., Lect. Notes Comput. Sci., 10863 LNCS, 516 (2018)

77. Juszczyk M., Sci. Rev. Eng. Environ. Sci., 26, 183 (2017)

78. Ma G., Liu Y., Shang S., Sustainability, 11, 4972 (2019)

79. Lee S.H., Kim H.Y., Shin H.K., Jang Y., Ahn Y.H., Int. J. Sustainable Build. Tech. Urban Dev., 8, 285 (2017)

80. Chang W., Zheng W., Struct. Concr., 20, 1328 (2019)

81. Prakash M., Manikandan S., Surenther I., Aswin Kumar M.N., Ilakkiya S., Menaka D., Int. J. Recent Technol. Eng., 7, 988 (2019)

82. Sadowski L., Nikoo M., Nikoo M., Comput. Concr., 22, 355 (2018)

83. Al-Gburi M., Jonasson J.-E., Nilsson M., Eur. J. Environ. Civ. Eng., 22, 226 (2018)

84. Zhou Q., Zhu F., Yang X., Wang F., Chi B., Zhang Z., Constr Build Mater, 153, 937 (2017)

85. Liu H., Zhang Y., Meas J Int Meas Confed, 133, 168 (2019)

86. Abambres M., Rajana K., Tsavdaridis K.D., Ribeiro T.P., Comput., 8, 2 (2019)

87. Trung N.T., Shahgoli A.F., Zandi Y., Shariati M., Wakil K., Safa M., Khorami M., Struct Eng Mech, 70, 639 (2019)

88. Terenchuk S., Pashko A., Yeremenko B., Kartavykh S., Ershov N., East.-Eur. J. Enterp. Technol., 3, 47 (2018)

89. Kim H., Ahn E., Shin M., Sim S.-H., Struct. Health Monit., 18, 725 (2019)

90. Park K.S., Hwang K.S., Lee K.M., Int. J. Innov. Technol. Explor. Eng., 8, 370 (2019)

91. Sun Y., Zhang X., Zhao X., Xin Q., Remote Sens., 10, 1459 (2018)

92. Cheng J.C.P., Wang M., Autom Constr, 95, 155 (2018)

93. Sun X., Wu S., Han G., Tian J., Cheng Q., J Vib Shock, 37, 221 (2018)

94. Ramezanshirazi M., Sebastiani D., Miliziano S., Lect. Notes Civ. Eng., 40, 490 (2020)

95. Golafshani E.M., Talatahari S., Appl. Soft Comput. J., 70, 263 (2018) 